\title{
Pozbawiony tyłułu esej o podróży do domu, którego nie ma i może nigdy nie będzie, albo do domu, który kiedyś należał do kogoś zupełnie innego
}

\author{
$\underline{\text { AndRZEJ PITRUS }}$ \\ Arab mi šahá na babu, \\ Já mu snad oči vydlabu, \\ Zabiju toho Barabu, toho Barabu, Alibabu, \\ Ze Sýrie. \\ Arab mi šahá na babu, \\ Já mu snad oči vydlabu, \\ Zabiju toho Barabu, toho Barabu, Alibabu, \\ Pokud mě nezabije on.
}

Jaromír Nohavica

Było jasne, że artyści odpowiedzą na kryzys imigracyjny dotykający nadal Europy. Zwykle czynili to w inny sposób niż pieśniarz z Ostravy, który - zapewne nieoczekiwanie także dla jego licznych polskich fanów - ujawnił sympatię dla czeskich nacjonalistów, domagających się wyrzucenia z ich kraju uchodźców - czasem uciekających przed wojną, kiedy indziej pragnących - jak każdy - lepszego życia, poczucia bezpieczeństwa, pracy. Jest jasne, że muszę napisać o imigrantach, bo nieoczekiwanie jestem jednym z nich. Miałem przyjechać tu na pół roku, żeby odpocząć, zwolnić, wszystko poukładać na nowo, a dziś to polski dom staje się tym drugim. Zapominam, gdzie mieszkają moje ulubione szklanki do whisky, w ubiegłym miesiącu to życzliwa sąsiadka przypomniała mi kod do domofonu... Zapomniałem... Tak szybko. A może jednak nie jestem imigrantem, choć przecież pasuję do definicji - przyjechałem do Hiszpanii z Polski z zamiarem osiedlenia się tu na stałe. Wszystko się zgadza.

Zacznę od anegdoty. Podobno prawdziwej. Oto pewna brytyjska turystka spędzająca wakacje w Hiszpanii, po powrocie do domu udała się do biura podróży ze skargą, że w hotelu, w którym została zakwaterowana było... za dużo Hiszpanów 
i dodatku nie mówili oni po angielsku. Nie... nie chodziło o obsługę, posługującą się dość sprawnie tym językiem, ale o innych letników. No i jeszcze na śniadanie były grzanki z jakąś pomidorową mazią, a na kolację taki dziwny żółty ryż z robakami. Brytyjczycy, Skandynawowie, Rosjanie, a także Polacy chętnie spędzają wakacje na Półwyspie Iberyjskim. Jeszcze chętniej osiedlają się tutaj z uwagi na klimat, relatywnie niskie koszty życia i styl odpowiadający tym, którym znudził się nieustanny wyścig szczurów. W moim mieście Torrevieja mieszka - wedle ostatniego spisu - około 47 procent Hiszpanów ${ }^{2}$. Reszta to ludzie innych narodowości. Najwięcej Brytyjczyków - około 13 procent. Polaków w ostatnim spisie odnotowano zaledwie nieco ponad 600. Dla porównania w Madrycie jest niemal 90 procent Hiszpanów, a to przecież stolica zwyczajowo przyciągająca przybyszów. Torrevieja to najbardziej multikulturowe miasto Hiszpanii - żyją tu ludzie reprezentujący 121 różnych narodowości.

Przyjęto nas życzliwie. Hiszpańscy sąsiedzi od razu pospieszyli z pomocą w drobnych sprawach, deklarując dalszą w razie potrzeby. Nie spotkaliśmy się dotąd z żadną formą niechęci. Hiszpanie są otwarci, nawet na konserwatywnym południu, choć obcokrajowcy nie zawsze zasługują na ich życzliwość. W lecie po centrum miasta snują się w strojach kąpielowych, a tutejsze prawo jest bezradne. Nie zabrania przechadzania się półnago, a nawet nago w miejscach publicznych. Straż miejska nie może im nawet zwrócić uwagi. Trochę jak w anegdocie o brytyjskiej turystce - mam wrażenie, że osadnicy z bogatszych krajów Europy są nie tyle imigrantami, ile nowymi kolonizatorami, przekonanymi że relatywnie grube portfele upoważniają ich do traktowania nowej ojczyzny jako niby-kraju, w którym pewne zasady życia społecznego mogą zostać zawieszone. A to czasem bywa niebezpieczne, zwłaszcza gdy ktoś próbuje na rondzie jechać pod prąd. Kim zatem jestem?

Imigracja jest konsekwencją kolonializmu, choć oczywiście jej mechanizmy są dzisiaj bardziej złożone ${ }^{3}$. W Holandii zamieszkuje spora społeczność surinamska ${ }^{4}$ licząca dzisiaj prawie 400 tysięcy osób. Niemal 6 procent mieszkańców tego kraju ma korzenie w byłej zamorskiej kolonii nazywanej do 1975 r. Gujaną Holenderską. W Niemczech żyje ponad 2,7 miliona ludzi, których co najmniej jedno z rodziców pochodzi z Turcji ${ }^{5}$. Tu jednak przyczyna jest inna - Niemcy sami zainicjowali przepływ ludności z tego kraju na początku lat 60., pragnąc pozyskać siłę roboczą. Scenariusze mogą być zatem bardzo różne. Mnie bardziej niż powiązanie kolonializmu i problemu kryzysu imigracyjnego interesuje sam fakt bycia obcym. Jakie są jego konsekwencje i konteksty?

W tym artykule przyglądam się pracom artystów działających na pograniczu teatru i kina. Zarówno scena, jak i film ustosunkowały się do kryzysu imigracyjnego, skupiając się przede wszystkim na jego wymiarze egzystencjalnym, choć niektórzy twórcy próbowali także analiz o charakterze politycznym. Szczególnie ciekawa wydaje się sytuacja, kiedy tak różne media spotykają się - film jako przekaźnik zdolny do utrwalania chwili i dramatyzmu rzeczywistości i teatr jako sztuka obecności i performatywności. Przeczucie mówi mi bowiem, że bycie obcym jest rodzajem roli - czasem sami ją odgrywamy, kiedy indziej reżyserem staje się „samo życie”. Rolą jest też bycie wobec obcego: żałosny rechot upadłego czeskiego barda albo pełne zrozumienia, a nic nieznaczące współczucie kanapowego marksisty. Czy podzieliłbyś się swoim domem z kimś, kto go nie ma? Czy 
tylko popijając single malta, rozprawiasz o tolerancji, prawie do swobodnego przemieszczania się i konieczności zniesienia wszelkich granic, w ciepłych kapciach, oglądając na sześćdziesięciocalowym ledowym telewizorze Fuocoammare Gianfranco Rosiego (2016).

Jednym z najbardziej niezwykłych zjawisk współczesnej sceny jest Théâtre du Soleil założony w Paryżu w 1964 r. Jego szefową jest Ariane Mnouchkine, ale w istocie grupa stanowi kolektyw ${ }^{6}$ tworzący kolejne przedsięwzięcia wspólnie, często z wykorzystaniem improwizacji, a także z aktywnym udziałem publiczności. Wszyscy na czas spektaklu tworzą społeczność dzielącą się nie tylko sztuką, ale także pożywieniem serwowanym przez samą Mnouchkine. Artystka i jej trupa od dawna interesują się filmem, w ich dorobku znajdziemy realizacje przeznaczone dla kina, a także projekty hybrydowe, w których bardzo często pojawiają się motywy związane z migracją, zwykle podejmujące aktualną problematykę nie wprost, lecz przez historię ${ }^{7}$ odczytywaną we współczesnym kontekście.

Praca zatytułowana Les Naufragés du Fol Espoir (Rozbitkowie z Fol Espoir) powstawała w dwóch etapach. W 2010 r. zrealizowano spektakl pokazywany przez dwa lata w siedzibie zespołu Cartucherie, a cztery lata później odbyła się premiera filmu, nakręconego w dużej mierze dzięki wsparciu finansowemu fanów zespołu. Podstawą scenariusza była w obydwu wypadkach niezbyt znana powieść Juliusza Verne'a - opublikowana już po śmierci pisarza i w istocie dokończona przez jego syna. Les Naufragés du Jonathan została opublikowana także w Polsce, najpierw w 1909 r., a więc natychmiast po wydaniu francuskim, w wersji skróconej (oryginał ma aż trzy tomy) jako Rozbitki (w piśmie „Przyjaciel Dzieci”), a potem w $1927 \mathrm{r}$. pod tytułem Ojczyzna rozbitków.

Ariane Mnouchkine zainteresowała się w niej nie tylko ulubionym motywem podróży, ale także wątkiem utopijnym. Powieść, a za nią projekt Słonecznego Teatru, opowiada bowiem o grupie rozbitków starających się zbudować idealne społeczeństwo na wyspie, na którą rzuca ich los po katastrofie statku. Mnouchkine podchodzi jednak do tekstu w sposób kreatywny. Nie jest to dosłowna adaptacja, lecz raczej wariacja na temat, wykorzystująca strukturę szkatułkową (analizuję tu drugą realizację filmowo-teatralną) - zarówno na płaszczyźnie fabularnej, jak i medialnej. Opowieść o rozbitkach została zapośredniczona przez historię o filmowcach realizujących w 1914 r. adaptację Verne’a. W całości mamy do czynienia z dwoma światami - ,realistycznym” sportretowanym klasycznie filmowymi środkami i scenicznym. Na tym drugim obszarze wykorzystano konwencję kina niemego - na ekranie widzimy i ekipę filmową, i wydarzenia rekonstruujące podróż opisaną przez autora Dzieci kapitana Granta. Nawiązania do wczesnego okresu kina nie są przypadkowe - pozwalają zachować parateatralny wymiar przedsięwzięcia, posługiwać się skrótem, przerysowaniem, wizualną metaforą, ale także osadzić akcję w ważnym dla Europy momencie. Akcja rozgrywa się bowiem w okresie bezpośrednio poprzedzającym pierwszą wojnę światową: zaczyna się w dniu zamachu na arcyksięcia Franciszka Ferdynanda, a kończy trzy dni przed oficjalnym początkiem ogólnoeuropejskiego konfliktu, kiedy dokonano zabójstwa francuskiego polityka Jeana Jaurèsa, znanego z pacyfistycznych wystąpień i nawoływania do wyciszenia konfliktu.

Dzieło Théâtre du Soleil ma niemal proroczy charakter. Film został po raz pierwszy pokazany w 2014 r., a więc przed rozpoczęciem największej fali kryzysu 
migracyjnego w Europie. Choć problem imigracji istniał już wcześniej (dopiero w 2015 r. doszło do jego eskalacji), a także - co w pewnym sensie jest odbiciem sytuacji z 1914 r. - był to moment załamania się europejskiej solidarności, klęski utopii tworzonej przez Unię Europejską skłonną przyjąć potrzebujących pomocy uchodźców z krajów ogarniętych wojną i biedą. Początkowa życzliwość wielu społeczeństw - sam miałem okazję obserwować jej przejawy, mieszkając w tym okresie w Berlinie - stopniowo ustępowała nieufności, a następnie wrogości spowodowanej między innymi atakami terrorystycznymi w wielu miastach Europy. Les Naufragés du Fol Espoir nie mówi o współczesnym kryzysie migracyjnym, ale w sposób bardziej uniwersalny i ponadczasowy opowiada o podróży, której impulsem jest nadzieja, i o niemożności stworzenia utopijnej wspólnoty. Także o tym, że mimo wszystko warto próbować ją budować.

Ariane Mnouchkine tworzy kino polityczne, ale - jak podkreśla Judith Miller ${ }^{8}$ - stawia przede wszystkim na sferę emocji. Teatr w ujęciu francuskiej reżyserki ma być miejscem gdzie spotykamy Innego i stajemy się Innym. Akcentowanie sztuczności, performatywności świata, procesu wcielania się, stawania się nie-sobą służy właśnie temu. Autorka monografii, cytując wypowiedzi artystki, mówi o tym, że Théâtre du Soleil realizuje pewien projekt edukacyjny, wskazując, jak można się uczyć dzięki rozumieniu historii, ale także, jak można stawać się lepszym doświadczając piękna, wartości i wspólnoty. Nazwa paryskiego teatru nie jest chyba przypadkowa. Choć Mnouchkine i jej zespół bardzo często mówią o rzeczach trudnych i bolesnych, ich spektakle są wypełnione światłem, radością i kreatywną energią rodzącą się na styku doświadczenia improwizujących aktorów i emocji widzów. Wystarczy, że na scenie pojawi się urodzona w Brazylii gwiazda trupy - Juliana Carneiro da Cunha. Wtedy jest magia i latają anioły, choć przecież Boga nie ma, zatem po co one?

Pasje teatralne i filmowe łączy także włoski reżyser Pippo Delbono. Podobnie jak Ariane Mnouchkine zderza obydwie formy ekspresji artystycznej w sposób daleki od widywanej na scenach teatralnych powierzchowności. Kino, bardzo często realizowane za pomocą prostych środków - tanich, amatorskich kamer, a nawet telefonu komórkowego - staje się w tym wypadku ekstensją zdarzeń teatralnych, w których mistrz, poza nielicznymi wyjątkami realizacji operowych - występuje osobiście. Zarówno teatr, jak i kino tego artysty mają charakter bardzo osobisty, a sztuka i życie splatają się w nich w ścisły sposób. Podobnie jak Pier Paolo Pasolini, jeden z mistrzów Włocha, Pippo Delbono, jest ateistą, paradoksalnie niezwykle często sięgającym po tematykę związaną z wiarą i religią. Tak jest również w Vangelo (Ewangelia) - spektaklu z 2015 r., który rok później doczekał się realizacji filmowej. Widowiska tego artysty nigdy nie mają fabularnego charakteru. Zwykle są budowane wokół monologu wygłaszanego na żywo przez Delbono - w części napisanego wcześniej, ale zwykle do pewnego stopnia improwizowanego. Poszczególne sceny, od realistycznych po wizyjne, cechują się autonomią i łączą się ze sobą na zasadzie luźnych skojarzeń. W Vangelo reżyser przywołuje postać matki, która kilka dni przed śmiercią zaproponowała mu, by zrealizował spektakl inspirowany Ewangeliami. Mógłbyś w nim opowiedzieć o miłości, której tak bardzo brakuje na świecie - poprosiła pani Delbono. I Pippo, dobry syn, opowiada, często wadząc się z Bogiem zbyt łatwo pozwalającym, by miłość poddawała się złu. W spektaklu pojawia się wątek uchodźstwa. W jednej ze scen prawdziwy ucieki- 
nier z Afganistanu opowiada o tym, jak był świadkiem utonięcia przyjaciela i kilku innych mężczyzn. Spotkamy go też przed teatrem, gdzie sprzedaje kwiaty... Po raz kolejny porządki mieszają się, bo teatr Pippo Delbono nie opowiada o świecie, ale jest z niego ulepiony. Od lat reżyser współpracuje z ludźmi wykluczonymi: chorymi, upośledzonymi fizycznie i umysłowo, bezdomnymi, a teraz imigrantami. Stają się oni pełnoprawnymi członkami zespołu, otrzymując szansę na prawdziwie dobrą zmianę ${ }^{9}$.

Motyw migracji jest jednym z wielu, jakie znajdziemy w wersji scenicznej. W filmie, zachowującym jednak wiele elementów teatralnych, trop ten wysuwa się na plan pierwszy. W pierwszej scenie powraca matka artysty ukazana w ostatnich chwilach jej życia, w kolejnych pojawiają się uciekinierzy zaproszeni przez artystę do współpracy. Po raz kolejny słuchamy dramatycznej historii Afgańczyka, ale istotą tego dzieła jest intrygujący eksperyment, w którym imigranci stają się performerami odgrywającymi, czasem à rebours, fragmenty Ewangelii, by w finale przyjąć imiona apostołów i zasiąść do wspólnej wieczerzy. Delbono pyta: $C z y$ widziałeś kiedyś kogoś, kto chodzi po wodzie, a odpowiada mu zanurzony w wodzie młody człowiek: Nie widziałem, żeby ktoś chodził, ale widziałem tych, co tonęli.

Pippo Delbono nie boi się emfazy, jego monologi są pełne emocji, czasem krzyku, a nawet łez. Nie mają jednak nic z operowej przesady, bo artysta cały czas dotyka rzeczywistości i przygarnia ludzi, którym Bóg nie chciał sprzyjać. Bóg, w którego Pippo Delbono nie wierzy. Jednym z nich był głuchoniemy i schorowany Bobò spotkany w przytułku w Aversie w 1997 r. Delbono zaopiekował się nim, podzielił się z nim swoim domem, a ten niezwykły, pełen charyzmy i wewnętrznego piękna człowiek stał się nie tylko towarzyszem życia reżysera i jego przyjacielem, ale także najważniejszym aktorem kompanii. Pojawia się też w Vangelo dłużej na scenie, w filmie tylko w krótkiej migawce. Po raz ostatni - Bobò zmarł 1 lutego 2019 r., po ponad dwudziestu latach wspólnego życia u boku jednego z największych artystów współczesnego teatru.

W bardziej klasyczny sposób teatr splata się z rejestracją filmową w spektaklu In unserem Namen (W naszym imieniu), który miałem okazję oglądać w listopadzie 2015 r. w berlińskim Gorki Theater - jednej z najbardziej zaangażowaych politycznie scen Europy. Problematyka związana z migracją pojawiała się wtedy w jego repertuarze często - w różnym ujęciu, także komediowym. Przywołuję właśnie ten, nie tylko z uwagi na włączenie tam segmentów filmowych, ale także na szczególny charakter elementów performatywnych. Sztuka powstała z inspiracji dwoma tekstami - tragedią Ajschylosa znaną w Polsce jako Błagalnice ${ }^{10}$ oraz dramatem Elfride Jelinek Die Schutzbefohlenen napisanym jako reakcja na tragedię, jaka rozegrała się w 2013 r. u brzegów Lampedusy.

Spektakl wyreżyserowany przez Sebastiana Nüblinga spotkał się z różnymi komentarzami - także krytycznymi ${ }^{11}$. Zarzucano mu między innymi, że dokonuje szantażu emocjonalnego, przemawiając przy tym w istocie do publiczności w dużej mierze podzielającej poglądy twórców nawołujących do przyjmowania imigrantów i ich integrowania ze społeczeństwem niemieckim. Nie można mu jednak odmówić siły wyrazu - mamy tu bowiem do czynienia ze szczególnym wariantem teatru dokumentalnego opartego na interakcji. Na czas spektaklu z głównej sali Gorkiego wyniesiono fotele, a aktorzy wchodzą na salę wraz z publicznością, rozmawiają $\mathrm{z}$ nią, nie pozwalają stać z boku. Obrazy wideo rzutowane na ściany są częściowo 
zarejestrowane, ale częściej są transmitowane na żywo. Kamera jest w teatrze po to, by uchwycić wybrane sceny i dokonać ich fałszywej „obiektywizacji” na podobieństwo telewizyjnych newsów. Wideo na żywo jest dziś wykorzystywane w teatrze aż za często i niejednokrotnie bez uzasadnienia. Tu jednak jego obecność ma sens i stanowi rodzaj kontrapunktu dla performatywnych interakcji między aktorami, pochodzącymi często z krajów, z których przybywali wtedy emigranci, a widzami Gorkiego.

Problematykę polityczną i społeczną coraz częściej podejmuje też Romeo Castellucci. Mistrz z Cezeny zaczynał od spektakli wyraźnie oderwanych od tu i teraz. Jego intrygujące plastycznie, alegoryczne wizje początkowo nie komentowały bieżących wydarzeń. Dziś często jest inaczej, choć jego język pozostaje rozpoznawalny, a jednocześnie ewoluuje. Jednym z jego wyróżników jest intermedialność, będąca nie tyle formą uatrakcyjnienia przekazu, ile jego rozszerzenia, prowadzącego w konsekwencji do efektu niedookreślenia, a czasem do zaplanowanej niepewności poznawczej widza ${ }^{12}$.

Problemu migracji Castellucci dotknął w Tratwie Meduzy (2018) - inscenizacji oratorium niemieckiego kompozytora Hansa Wernera Henze, który choć korzystał z technik serializmu, nie unikał muzyki tonalnej, a nawet rocka i jazzu. Efekty były często kontrowersyjne, choć zwykle oryginalne. W utworze z 1971 r. nawiązuje do obrazu Théodore'a Géricault, a ściślej do wydarzeń przedstawionych alegorycznie w 1918 r. przez francuskiego malarza - tragedii, jaka rozegrała się kilka lat wcześniej u wybrzeży Afryki. Katastrofa „Meduzy”, na której pokładzie było ponad 400 pasażerów, miała fatalne skutki. Przepełniony statek nie miał odpowiedniej liczby szalup ratunkowych, na skutek czego ponad 150 osób próbowało ratować się na prymitywnej tratwie. Do brzegu dotarło ledwie 15.

Historia ta kojarzy się dziś oczywiście z dramatem uciekinierów, którzy zginęli u brzegów Lampedusy, ale przecież nie tylko. Katastrofa na Morzu Śródziemnym była największa, ale woda zabrała życie także wielu innym zdesperowanym śmiałkom. Inaczej niż Nübling, Castellucci nie proponuje teatru dokumentalnego. Choć na scenie jest kamera i postać dziennikarki (w libretcie oratorium jest to Śmierć), na zawieszonym nad sceną ekranie nie zobaczymy ani przekazu na żywo z teatru, ani rzeczywistego zapisu dramatu imigrantów. W scenie finałowej widzimy wprawdzie wnętrze sali, ale jest ona pusta. Ciekawsze jest to, co stanowi ilustrację dzieła Henzego w trakcie całego trwania utworu. Bohaterem projekcji wideo jest Mamadou Ndiaye - Senegalczyk, o którym dowiadujemy się niewiele: ma żonę, dwójkę dzieci, wyznaje islam. Zgodził się wziąć udział w niezwykłej próbie - na prośbę reżysera spędził w sumie 24 godziny w wodzie na pełnym morzu - w miejscu, gdzie przed laty rozegrała się tragedia „Meduzy”. Przez cztery dni zmagał się z żywiołem wody i zimnem wciągany do szalupy ratunkowej tylko wtedy, kiedy całkowicie opadał z sił. Przekaz oglądany przez widzów jest oczywiście skróconym zapisem tego osobliwego performansu, bo dzieło Henzego trwa około 80 minut. Wyobraźmy sobie, jak wyglądała ta próba z perspektywy Mamadou, a następnie wyobraźmy sobie kogoś, kto nie ma poczucia bezpieczeństwa gwarantowanego przez ratowników gotowych w każdej chwili wesprzeć walczącego z falami pływaka. Próba podjęta przez Senegalczyka była trudna i niebezpieczna, jednak odległa od prawdziwie dramatycznych losów uchodźców pragnących za wszelką cenę dostać się do Europy - utożsamianej przez nich z Rajem na Ziemi. 
Wracam raz jeszcze do Słonecznego Teatru Ariane Mnouchkine, bo przecież Rozbitkowie nie są ich pierwszym filmospektaklem podejmującym problematykę „wędrówki ludów”. Wcześniej, w 2006 r., powstała Ostatnia karawana (Le dernier caravansérail) podobnie jak omówione wyżej dzieło trupy wykorzystująca hybrydowy język czerpiący z kina i teatru. Tym razem nie jest to jednak jedna opowieść, lecz mozaika przywodzącą na myśl słynne Efemerydy (Les Ephémères, 2008) - bodaj najgłośniejszy spektakl zespołu.

Trwający ponad cztery godziny utwór został podzielony na krótkie sceny ukazujące tym razem nie problem kolonizacji, lecz imigracji. Mnouchkine nie skupia się na jednym wątku, ale ukazuje problem w skali globalnej: przybysze szukają nowego domu w Australii, próbują przedostać się do Wielkiej Brytanii przez podwodny tunel, ryzykują życie, wsiadając na prymitywne tratwy mające przewieźć ich do celu. Całość została rozegrana w sztucznych, jawnie umownych dekoracjach, a aktorzy grają w sposób bliższy teatrowi niż kinu. My jednak oglądamy Karawanę okiem kamery, a zastosowane przez zespół środki są bardzo często próbą zbudowania metadyskursu poświęconego zderzeniu wypowiedzi teatralnej i filmowej.

W wielu scenach akcja rozgrywa się na ruchomych platformach będących rodzajem mobilnego miniaturowego planu filmowego. Aktorzy, aby zamarkować rzeczywisty lub pozorny ruchu kamery, przemieszczają się na niewielkich wózkach poruszanych przez nieukrywających swej obecności techników.

Mnouchkine osiąga w Ostatniej karawanie efekt rzadko oglądamy w kinie czy teatrze. Głęboki, przejmujący dramatyzm ukazanych w tym utworze sytuacji zostaje bowiem skonfrontowany $\mathrm{z}$ teatralną umownością. W rezultacie powstaje efekt osobliwego migotania, w którym widz jest zmuszony odnaleźć się między filmowym ,zawieszeniem niewiary" a świadomością uczestnictwa w spektaklu, w którym ludzkie dramaty są performowane przez uczestniczących w wydarzeniu aktorów.

Choć prace Słonecznego Teatru nie mają wiele wspólnego z teatrem dokumentalnym, scenariusz widowiska powstał na podstawie rozmów z uchodźcami, których Mnouchkine spotkała w Sangatte Centre ${ }^{13}$ podczas trasy innego spektaklu. Ich losy zostały odegrane przez 36 aktorów, wcielających się jednak w ponad 160 różnych postaci, ale to prawdziwi uchodźcy, którzy opowiedzieli o swoich losach, są faktycznymi autorami widowiska, choć ich wypowiedzi zostały zapewne poddane edycji przez Ariane Mnouchkine.

Ostatnia karawana została podzielona na dwie części. Pierwsza, zatytułowana Okrutna rzeka, mówi o przyczynach, dla których bohaterowie postanawiają uciec z własnej ojczyzny (przede wszystkim z Afganistanu, ale i z innych zapalnych punktów w Europie, m.in. z Czeczenii). Druga - nosząca tytuł Źródła i cele, pokazuje problemy, z jakimi uciekinierzy spotykają się w miejscach, do których udało im się dotrzeć. To ta część wydaje się szczególnie przejmująca, bo Mnouchkine nie idealizuje imigrantów, pokazując, jak ci, którzy już znaleźli swoje miejsce w ziemi obiecanej, wykorzystują, okradają i poniżają własnych rodaków. W jej widowisku jest wiele ról do zagrania - dosłownie i w przenośni. Widzowie, dzięki zastosowaniu rozwiązań z pogranicza filmu i teatru, raz po raz są konfrontowani z sytuacjami, w których wszyscy uczestnicy tego politycznego dramatu muszą, a czasem po prostu chcą odegrać napisaną dla nich rolę.

Hiszpania, która powoli staje się domem, nie jest moim pierwszym wygnaniem. Zawsze miałem naturę włóczykija, ale z czasem przystawałem w mojej gonitwie 
po świecie coraz częściej, by w końcu zamieszkać w Berlinie, na tyle bliskim naszemu krakowskiemu domowi, że przez kilka lat udawało się nam żyć w dwóch miastach niemal równocześnie. W 2015 r. poznałem tam Fatimę - młodą dziewczynę z Portugalii, która przyjechała do Niemiec szukać lepszej pracy. Spotkaliśmy się w szkole językowej, do której postanowiłem się zapisać, zostając chyba jej najstarszym studentem. Młodzi ludzie z mojej klasy przyjęli mnie jak swojego. Czasem, już po zakończeniu intensywnego kursu, umawialiśmy się na popołudniowe lub wieczorne wypady, czasem na piwo, kiedy indziej po prostu by pogadać po niemiecku, zapalić skręta, posnuć się po ulicach Kreuzbergu. Kiedyś Fatima nieoczekiwanie nie stawiła się w umówionym miejscu. Bała się wyjść z domu, bo pod jej oknami odbywała się agresywna demonstracja Pegidy. Fatima miała w kieszeni unijny paszport, urodziła się w Portugalii podobnie jak jej rodzice i dziadkowie. Jej skóra jest jednak czarna i to właśnie jej kolor napisał dla niej rolę do zagrania. Kiedy indziej Mohamet wszedł do klasy ze spuszczoną głową, zawstydzony. Było to dzień po tym, jak zamachowiec, islamski fanatyk wjechał w tłum ciężarówką na placu w okolicach Dworca Zoo. Mohamet pochodzi z Syrii, dawno nie był w ogarniętej wojną ojczyźnie, jego żona jest Niemką, ale twarz na zawsze naznaczona stygmatem. Kiedyś niemiecka staruszka splunęła mu pod nogi, kiedy na ulicy rozmawiał z bratem po arabsku o tym, że chce porzucić islam, choć to dla niego niełatwa decyzja.

Ja za tydzień wracam do domu, który kiedyś był domem kogoś innego. W moim mieście nieruchomości nadal drożeją, stając się coraz bardziej nieosiągalne dla młodych Hiszpanów, zmuszonych coraz częściej szukać pracy tam, gdzie nie rosną pomarańcze.

ANDRZEJ PITRUS

Torrevieja - Kraków, kwiecień - czerwiec 2019

${ }^{1}$ Mam wszystkie płyty Nohavicy. Kilka unikatów, oryginalnych winyli z dawnych lat. Nie mogę już ich jednak słuchać. Rubaszny, wulgarny tekst napisany językiem mowy nienawiści przekreśla dla mnie głęboki sens Komety - najpiękniejszego i najmądrzejszego utworu czeskiego barda. Dlaczego? Przecież słucham Ryszarda Wagnera, który był antysemitą i Carla Orffa sympatyzującego z nazistami. Zachwycają mnie filmy Leni Riefenstahl, choć propagują zbrodniczą ideologię, w imię której wymordowano miliony ludzi. Dlaczego nie umiem słuchać Jarka, którego kiedyś darzyłem taką sympatią?

${ }^{2}$ http://www.torrevieja.com/eng/torrevieja/torrevieja\%E2\%80\%99s-population-risesto105,270-citizens.html (dostęp: 11.05.2019)

${ }^{3}$ Bardzo ciekawą publikacją na ten temat jest: Colonialism and Beyond: Race and Migration from a Postcolonial Perspective, red. E. Bischoff, E. Engel, Lit Verlag, Berlin Wien 2013.
${ }^{4}$ Więcej na ten temat w: E. Sint Nicolaas, Shackles and Bonds: Suriname and the Netherlands From 1600, Vantilt Publishers, Nijmegen 2018.

${ }^{5}$ Więcej: J. A. Miller, Turkish Guest Workers in Germany: Hidden Lives and Contested Borders, University of Toronto Press, Toronto 2018.

${ }^{6}$ Por. D. Williams, Collaborative Theatre. Le Théâtre du Soleil Sourcebook, Routledge, London - New York 2005. W publikacji tej znajdziemy wiele tekstów źródłowych (przede wszystkim wywiadów) wyjaśniających ideę pracy zbiorowej w zespole.

${ }^{7}$ Problematyke tę ciekawie opisuje Judith Miller. Por. tejże, Ariane Mnouchkine, Routledge, London - New York 2018.

8 Tamże, s. 56 i dalsze.

${ }^{9}$ Sam reżyser podkreślał wielokrotnie, że nie dla taniego efektu, czy egzotyki szuka ludzi marginalizowanych, ale zatrudnia tych, którzy są prawdziwymi artystami, zdolnymi, także z uwagi na ich ograniczenia i traumatyczne 


\section{ANDRZEJ PITRUS}

przeżycia oddać to, czego nie są w stanie zagrać zawodowi aktorzy. Por. For a Political Theatre: Pippo Delbono in conversation with Alessandra De Martino, w: P. Puppa, A. De Martino, P. Toninato, Differences on Stage, Cambridge Scholars Publishing, Newcastle 2013, s. 239-247.

${ }^{10}$ Grecki tytuł I $\kappa \varepsilon ́ \tau ı \delta \varepsilon \varsigma$ oznacza dosłownie „muszle”.

${ }^{11} \mathrm{Z}$ reakcjami niemieckich krytyków można zapoznać się tu: https://www.nachtkritik.de/index.php?option $=$ com_content\&view $=$ article $\& \mathrm{i}$ $\mathrm{d}=11767$ :in-unserem-namen-sebastiannuebling-entwirft-am-berliner-gorki-theater- eine-abend-zur-fluechtlingspolitik-nacha i s chylos-elfriede-jelinek-undbundestagsprotokollen $\&$ catid $=52 \&$ Itemid $=90$ (dostęp: 11.05.2019).

${ }_{12}$ Pisze o tym Sarah Bay-Cheng. Tejże, Portal: Time and Stace. Temporality, w: Mapping Intermediality in Performance, red. S. Bay-Cheng, Ch. Kattenbelt, A. Lavender, R. Nelson, Amsterdam University Press, Amsterdam 2010, s. 83-85.

${ }^{13}$ Pisze on tym np. Allison Jeffers. Tejże, Refugees, Theatre, and Crisis Performing Global Identities, Palgrave Macmillan, London 2012. 